\title{
Extent of Involvement of Women in Agriculture in the Major Crops of Telangana State
}

\author{
Surkanti Prathibha $^{1^{*}}$, R. Geetha Reddy ${ }^{1}$, S. L. Kameswari ${ }^{1}$ and S. Suchiritha Devi ${ }^{2}$ \\ ${ }^{1}$ Department of Extension Education and Communication Management, Hyderabad, \\ Professor Jayashankar Telangana State Agricultural University, Telangana, India \\ ${ }^{2}$ Department of Foods and Nutrition, PG\&RC, Rajendranagar, Hyderabad, Professor \\ Jayashankar Telangana State Agricultural University, Telangana, India
}

*Corresponding author

\section{A B S T R A C T}

\section{Keywords}

Farm women, Agricultural activities, Extension contact

\section{Article Info}

Accepted:

22 June 2020

Available Online:

10 July 2020
The present study was undertaken to study the involvement of women in agricultural activities. Total sample of 120 farm women were selected through purposive random sampling method. Exploratory research design was used for the study. The study was conducted by using a structured interview schedule. The data was analyzed using frequency, percentage and mean percent score. In the study, the result revealed that majority of the respondents were belonged to middle age group (52.50\%), illiterates $(50.00 \%)$ with agriculture + beedi making $(58.33 \%)$ as occupation, medium income group (41.67\%) with small (2.5-5 acres) landholding (58.33\%) with low extension contact $(88.33 \%)$. Majority of the farm women were involved in sowing \& transplantation $(96.11 \%)$, weeding and hoeing $(93.33 \%)$, picking $(89.17 \%)$, harvesting $(75.28 \%)$, drying $(68.33 \%)$, cleaning \& separation $(52.50 \%)$ and winnowing \& cleaning $(43.33 \%)$.

\section{Introduction}

In the developing world, women contribute heavily to agriculture, particularly in the production of household food. The FAO (United Nations Food and Agriculture Organization), IFAG (International Fund for Agricultural Development) and other international agencies estimate that women account for $70-80 \%$ of household food production in Sub-Saharan Africa, 65\% in Asia and $45 \%$ in Latin America and the Caribbean.
Women play a very important role in the development of agriculture in an agrarian country like India and contribute three-fourths of the total labour required. Most of the women were involved in the time consuming, drudgery involved, and unskilled tasks such as transplantation, harvesting, and intercultural operations.

In Indian society, women have a multidimensional role. The largest number of women in India is engaged in farming operations either as cultivators or as 
supervisors or as agricultural laborers. They are the main decision makers and participants in various agricultural operations like seed sowing, transplanting, weeding, harvesting, threshing, application of manure, storage of seeds and food grains and post-harvest home level processing. Yadav (2017)

The main objectives of this study include to study the profile characteristics of the farm women. And also to study the extent of involvement of women in agricultural activities.

\section{Materials and Methods}

In the present study Exploratory research design was followed. As the investigator was studying in Telangana state so it was selected purposively. Nizamabad and Karimnagar districts were selected purposively because of the highest cropping intensity. Out of two selected districts, one mandal from each district and 2 villages from each mandal covering 30 farm women from each village, thus constituting a total sample of 120 farm women were selected for the present study. Purposive random sampling was adopted for sample selection with the criteria of involvement of women in agricultural activities of major crops such as rice, cotton, turmeric, maize etc. The data was organized, tabulated and classified using qualitative and quantitative classification and subjected to statistical tests. The statistical tools were Frequency, Percentage and Mean percent score.

\section{Results and Discussion}

\section{Profile characteristics of the farm women}

\section{Age}

Table 1 indicates that majority $(52.50 \%)$ of the respondents belonged to middle age followed by young age $(25.00 \%)$ and old age
$(20.00 \%)$. The results were supported by Kumari (2018).

\section{Education}

Table 1 depicts that half of the respondents $(50.00 \%)$ were belonged to illiterates followed by primary school education $(14.17 \%)$, secondary school education $(23.33 \%)$ and college education (12.50\%).

The results were in accordance with the results of Verma and Singh (2019).

\section{Occupation}

It was evident from the table. 1 that majority $(58.33 \%)$ of respondents were belonged to agriculture + beedi making category followed by agriculture $(20.83 \%)$, agriculture + agricultural labour (10.00\%), agricultural labour + beedi making (6.67\%) and agricultural labour $(4.17 \%)$. The results were in line with the results of Bairve (2013).

\section{Annual Income}

The results in the Table. 1 clearly indicated that maximum number $(41.67 \%)$ of the respondents were belonged to medium annual income group followed by 35.00 per cent of the respondents were belonged to low annual income group and $23.33 \%$ of the respondents were belonged to high annual income group. Similar results were found by Jain (2007).

\section{Landholding}

Table.1indicated that more than half $(58.33 \%)$ of the respondents had small landholding (2.5-5 acres) followed by 18.33 per cent of the respondents were had marginal land holding (Up to 2.5 acres), 12.50 per cent of the respondents had medium landholding (510 acres), 6.67 per cent of the respondents had large land holding (> 10 acres) and only 
4.17 per cent of the respondents had no Singotiya et al., (2014). landholding. Similar results were found by

Table.1 Distribution of farm women according to their profile characteristics $n=120$

\begin{tabular}{|c|c|c|c|}
\hline S. No. & Category & Frequency & Percentage $(\%)$ \\
\hline \multicolumn{4}{|c|}{ Age } \\
\hline a) & Young (20-35) & 33 & 27.50 \\
\hline b) & Middle (35-50) & 63 & 52.50 \\
\hline c) & Old (Above 50) & 24 & 20.00 \\
\hline \multicolumn{4}{|c|}{ Education } \\
\hline a) & Illiterate & 60 & 50.00 \\
\hline b) & Primary School & 17 & 14.17 \\
\hline c) & Secondary School & 28 & 23.33 \\
\hline d) & College Education & 15 & 12.50 \\
\hline \multicolumn{4}{|c|}{ Occupation } \\
\hline a) & Agriculture & 25 & 20.83 \\
\hline b) & Agriculture + Agricultural labour & 12 & 10.00 \\
\hline c) & Agriculture + Beedi making & 70 & 58.33 \\
\hline d) & Agricultural labour & 5 & 4.17 \\
\hline e) & Agricultural labour + Beedi making & 8 & 6.67 \\
\hline
\end{tabular}

4. Annual Income

\begin{tabular}{|l|l|l|l|}
\hline a) & Low (Below Rs.60,000) & 42 & 35.00 \\
\hline b) & Medium (Rs.60,000-1,20,000) & 50 & 41.67 \\
\hline c) & High (Above Rs.1,20,000) & 28 & 23.33 \\
\hline
\end{tabular}

5. Landholding

\begin{tabular}{|l|l|c|c|}
\hline a) & No land & 5 & 4.17 \\
\hline b) & Marginal (Up to 2.5 acres) & 22 & 18.33 \\
\hline c) & Small (2.5-5 acres) & 70 & 58.33 \\
\hline d) & Medium (5-10 acres) & 15 & 12.50 \\
\hline e) & Large (> 10 acres) & 8 & 6.67 \\
\hline
\end{tabular}

6. Extension agency contact

\begin{tabular}{|l|l|c|r|}
\hline a) & Low $(0-4)$ & 106 & 88.33 \\
\hline b) & Medium (4-8) & 14 & 11.67 \\
\hline c) & High $(8-12)$ & 0 & 0.00 \\
\hline
\end{tabular}


Table.2 Distribution of farm women according to their extent of involvement in pre-sowing and sowing activities $n=120$

\begin{tabular}{|l|l|c|c|}
\hline \multirow{2}{*}{ S. No. } & \multicolumn{1}{|c|}{ Name of the activity } & \multicolumn{2}{|c|}{ Extent of involvement } \\
\cline { 2 - 4 } & Pre sowing and sowing activities & MPS & Rank \\
\hline 1. & Land preparation & 43.89 & II \\
\hline 2. & Manuring of fields & 12.22 & VI \\
\hline $\mathbf{3 .}$ & Pre sowing irrigation & 18.61 & III \\
\hline 4. & Seed treatment & 0.00 & VIII \\
\hline $\mathbf{5 .}$ & Sowing and transplantation & 96.11 & I \\
\hline 6. & Raising vegetable nursery & 15.28 & V \\
\hline 7. & $\begin{array}{l}\text { Application of basal dose of } \\
\text { fertilizers }\end{array}$ & 15.83 & IV \\
\hline 8. & $\begin{array}{l}\text { Maintenance of agriculture } \\
\text { implements }\end{array}$ & 1.67 & VII \\
\hline
\end{tabular}

Table.3 Distribution of respondents according to their extent of involvement in intercultural activities $n=120$

\begin{tabular}{|l|l|c|c|}
\hline S. No. & \multicolumn{1}{|c|}{ Name of the activity } & \multicolumn{2}{|c|}{ Extent of involvement } \\
\cline { 2 - 4 } & Intercultural activities & MPS & Rank \\
\hline 1. & Application of fertilizer & 56.94 & V \\
\hline 2. & Weeding and hoeing & 93.33 & I \\
\hline 3. & Picking & 89.17 & II \\
\hline 4. & Irrigation & 25.00 & VI \\
\hline 5. & Spraying & 3.33 & VII \\
\hline 6. & Dusting & 1.11 & VIII \\
\hline 7. & Harvesting & 75.28 & III \\
\hline 8. & Drying & 68.33 & IV \\
\hline
\end{tabular}

Table.4 Distribution of respondents according to their extent of involvement in post-harvest activities $n=120$

\begin{tabular}{|c|c|c|c|}
\hline \multirow[t]{2}{*}{ S. No. } & \multirow{2}{*}{$\begin{array}{l}\text { Name of the activity } \\
\text { Post-harvest activities }\end{array}$} & \multicolumn{2}{|c|}{ Extent of involvement } \\
\hline & & MPS & Rank \\
\hline 1. & $\begin{array}{l}\text { Transportation of the produce } \\
\text { to threshing floor }\end{array}$ & 2.50 & VIII \\
\hline 2. & Threshing & 7.50 & VII \\
\hline 3. & Winnowing and cleaning & 43.33 & II \\
\hline 4. & Weighting and bagging & 23.89 & V \\
\hline 5. & Storing and treating grain & 21.11 & VI \\
\hline 6. & Cleaning and separation & 52.50 & I \\
\hline 7. & Collection of harvested crop & 39.72 & III \\
\hline 8. & Piling up of grains & 38.88 & IV \\
\hline
\end{tabular}


Fig.1 Distribution of farm women according to their extent of involvement in pre-sowing and sowing activities

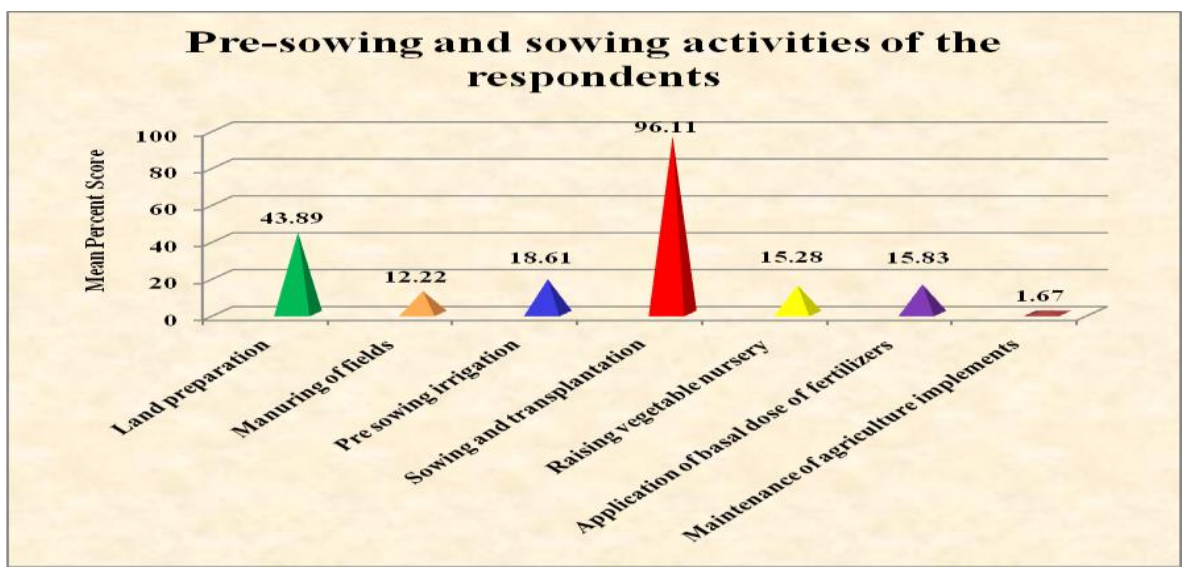

Fig.2 Distribution of respondents according to their extent of involvement in intercultural activities

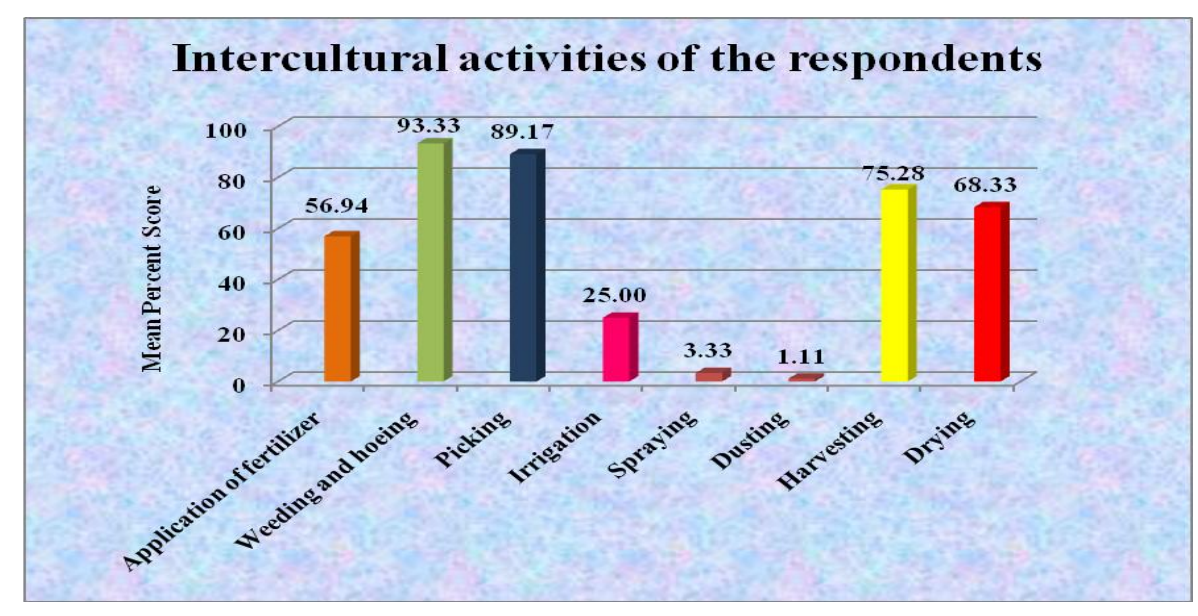

Fig.3 Distribution of respondents according to their extent of involvement in post-harvest activities

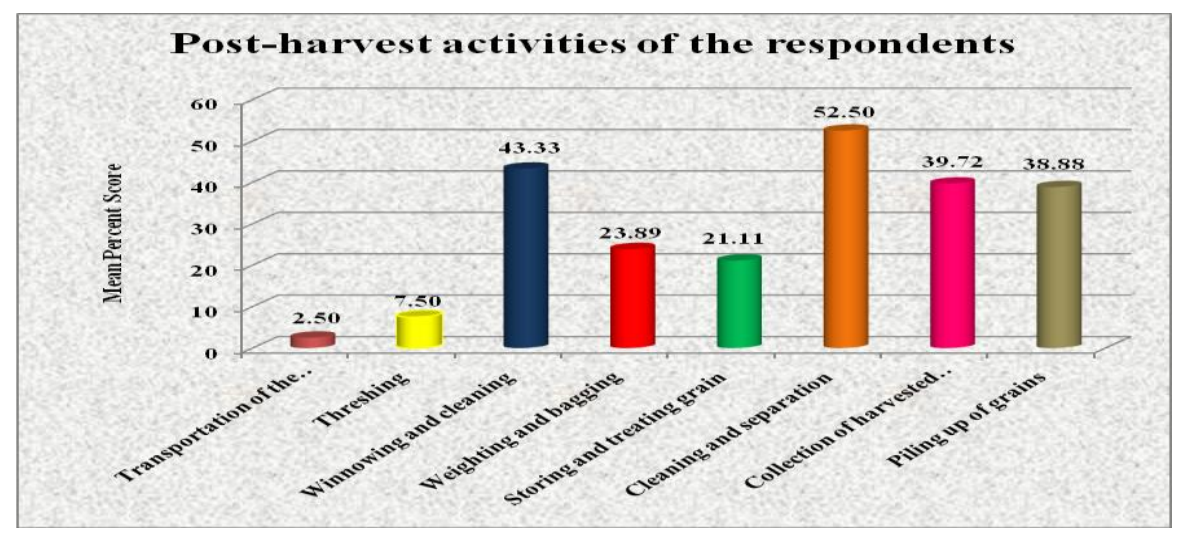




\section{Extension agency contact}

Table. 1 showed that majority $(88.33 \%)$ of the respondents had low extension agency contact followed by medium extension contact $(11.67 \%)$ and none of the respondents had high extension contact. Similar results were quoted by Singotiya et al., (2014).

\section{Extent of involvement of women in agricultural activities}

From table. 2 revealed that majority of the farm women were involved in "sowing and transplantation" (MPS 96.11) as it was perceived to the great extent by farm women. The second most important activity in which women were involved was "land preparation" (MPS 43.89), followed by "pre sowing irrigation" (MPS 18.61), "application of basal dose of fertilizers" (MPS 15.83), "raising vegetable nursery" (15.28), "manuring of fields" (12.22) and "maintenance of agricultural implements" (1.67) which were ranked third, fourth, fifth, sixth and seventh respectively (Fig.1.). Similar results were reported by Singh et al., (2019) and Kumari (2018).

From table.3, it was found that majority of the farm women were involved in "wedding and hoeing" (MPS 93.33), as it was perceived to the great extent by farm women. The second most important activity in which women were involved was "picking" (MPS 89.17) followed by "harvesting" (MPS 75.28), "drying" (MPS 68.33), "application of fertilizer" (MPS 56.94), “irrigation” (MPS 25.00) which were ranked third, fourth, fifth and sixth respectively. While "spraying" (MPS 3.33) and "dusting" (MPS 1.11) were found to be less involved activites among the farm women (Fig.2.). Similar results were found by Rani (2019), Kumari (2018) and Yadav (2017).
Table.4clearly shows that majority of the farm women were involved in "cleaning and separation" (MPS 52.50), as it was perceived to the great extent by farm women. The second most important activity in which women were involved was "Winnowing and cleaning" (MPS 43.33) followed by "Collection of harvested crop" (MPS 39.72), "Piling up of grains" (MPS 38.88), "Weighting and bagging" (MPS 23.89), "Storing and treating grain" (MPS 21.11) which were ranked third, fourth, fifth and sixth respectively. While "Threshing" (MPS 7.50) and "Transportation of the produce to threshing floor" (MPS 2.50) were found to be less involved activites among the farm women (Fig.3.). The results were supported by Dudi and Meena (2017), Jahan and Khan (2016).

In conclusion the present study concluded that the women play a significant and crucial role in agricultural activities of major crops such as rice, cotton, turmeric, maize etc. Rural women constitute the most important work force in Indian economy and majority of the agricultural operations were carried out by the farm women. From the above study, it can be concluded that majority of the respondents were belonged to middle age group $(52.50 \%)$, illiterates $(50.00 \%)$ with agriculture + beedi making $(58.33 \%)$ as occupation, medium income group $(41.67 \%)$ with small (2.5-5 acres) landholding (58.33\%) with low extension contact (88.33\%). In pre sowing and sowing activities, majority of the farm women were involved in sowing, transplantation and land preparation.

In intercultural activities, majority of the farm women were involved in wedding and hoeing followed by picking and drying. In post harvest activities, majority of the farm women were involved in cleaning and separation followed by winnowing and cleaning and collection of harvested crop. 


\section{References}

Bhairve, V. 2013.A study on Women's participation and Decision making pattern in Agriculture activities in Sehore district of Madhya Pradesh. M.Sc. Thesis. Jawaharlal Nehru Krishi Vishwa Vidyalaya, College of Agriculture, Jabalpur (M.P.).

Dudi, A. and Meena, M.L. 2017. Participation and decision making pattern of farm women in agriculture. Asian Journal of Home Science. 12 (1): 109-113

Jahan, N and Khan, N. 2016.To study the participation of farm women in various agriculture and allied activities.International Journal of Home Science. 2(2): 180- 186.

Jain, S. 2007. A study on Participation of Farm women in Agriculture and Decision making in Jhabua District of Madhya Pradesh. M.Sc. Thesis. Jawaharlal Nehru Krishi VishwaVidyalaya. Jabalpur.

Kumari, A.R. 2018. Role of farm women in agriculture and their involvement in decision making - A study in Deoria district of Uttar Pradesh.Journal of Pharmacognosy and Phytochemistry. SP1: 1249-1253.

Rani, P. 2019. Female agricultural workers in Haryana: A study of Karnal district. International Journal of Research and Analytical Reviews.6 (1).

Singh, P., Dubey, S.K and Pandey, S. 2019. Occupational Health Hazard among Farm Women in Kannauj district of Uttar Pradesh. Journal of Community Mobilization and Sustainable Development. 14(1): 5-10.

Singotiya, P.,Khare, N.K and Agrawal, S.2014. Role of tribal farm women in decision making towards agricultural operations. Advance Research Journal of Social Science. 5(2): 242-244.

Verma, R and Singh, V. 2019.Health Problems Faced by Farm Women during Weeding Activity. Indian Journal of Ecology.

Yadav, S. 2017. Role of rural women in Agricultural activities in Jaipur district of Rajasthan. M.Sc. Thesis. S.K.N Agriculture University, Jobner.

\section{How to cite this article:}

Surkanti Prathibha, R. Geetha Reddy, S. L. Kameswari and Suchiritha Devi, S. 2020. Extent of Involvement of Women in Agriculture in the Major Crops of Telangana State. Int.J.Curr.Microbiol.App.Sci. 9(07): 3903-3909. doi: https://doi.org/10.20546/ijcmas.2020.907.457 